\title{
PENGARUH PERSEPSI GURU TENTANG KREDIBELITAS KEPALA SEKOLAH TERHADAP PENINGKATAN KINERJA PROFESIONALNYA
}

\author{
Sudanto ${ }^{1}$ dan Said Maskur ${ }^{2}$ \\ ${ }^{1}$ STAIN Sultan Abdurrahman Kepri \\ sultan.irianto5588@gmail.com \\ ${ }^{2}$ STIT Ar-Risalah Inhil Riau \\ said.maskun@gmail.com
}

\begin{abstract}
Abstrak
Kinerja guru sering kali dipengaruhi oleh pola kepemimpinan kepala sekolah. Sedangkan kepala sekolah, dalam bersikap dan berkomunikasi, juga sangat dipengaruhi oleh faktor internal pribadinya maupun faktor eksternalnya. Dalam setiap sikap dan pola komunikasi yang digunakan oleh kepala sekolah akan memunculkan persepsi dari masing-masing guru yang akan memunculkan sikap lebih lanjut. Dalam penelitian ini, studi kasus dilakukan terhadap guru-guru MA Darul Falah Batam dengan fokus pada pengaruh persepsi guru tentang kredibelitas kepala sekolah dalam peningkatan kinerjanya dengan metode kuantitatif. Dari hasil penelitian, para guru masih memberikan nilai bagus atas kredibelitas kepala sekolah. Sedangkan sebagian kecilnya saja yang menyatakan tidak kredibel dan tidak tahu. Kepercayaan itu terbangun karena pola komunikasi dan gaya kepemimpinan kepala sekolah yang mampu berberikan dampak positif terhadap persepsi guru. Sedangkan terkait kinerja pada guru masih menunjukan profesionalitasnya yang dibuktikan dengan beberapa prestasi dari sekolah tersebut. Dalam penelitian ini juga terungkap bahwa persepsi dan kinerja tidak sepenuhnya karena faktor kepemimpinan dalam manajemen, melainkan juga faktor psikologis dan komunikasi yang turut membantu membangun persepsi terebut.
\end{abstract}

Abstract: Teacher performance is often influenced by the principal's leadership pattern. While the principal, in behaving and communicating, is also very much influenced by his personal internal factors and external factors. In every attitude and pattern of communication used by the principal will bring up the perception of each teacher that will bring further attitudes. In this study, a case study was carried out on MA Darul Falah Batam teachers with a focus on the influence of teachers' perceptions of the credibility of the principal in improving their performance with quantitative methods. From the results of the study, the teachers still provide good value for the credibility of the principal. While only a small part of them stated that they were not credible and did not know. Trust is built because of the communication patterns and leadership styles of principals that are able to have a positive impact on teacher perceptions. While the performance related to the teacher still shows his professionalism as evidenced by several achievements of the school. In this study also revealed that perception and performance were not entirely due to factors of leadership in management, but also psychological and communication factors that helped build the perception.

Kata Kunci : manajemen komunikasi, profesionalisme guru, manajemen sekolah

\section{Pendahuluan}

Mencapai tujuan pendidikan dengan cara yang efektif dan efisien merupakan tujuan dari manajemen pendidikan. ${ }^{1}$ Dalam hal ini, kinerja seluruh elemen merupakan suatu komponen yang tidak terpisahkan dari pola

1 Andi Rasyid Pananrangi, Manajemen Pendidikan, Celebes Media Perkasa, 2017, hal. 12 
menajemen. Seiring dengan perubahan kurikulum dan mekanisme pengajaran serta perkembangan teknologi, maka diperlukan juga perubahan pola manajemen sebagai upaya penyesuaian dengan zaman, baik dari struktur, strategi, pengawasan, perencanaan, dan hal lain yang terkait dengan kelembangan pendidikan. Yang tidak kalah penting ialah pengelolaan sumber daya manusia (SDM). Setiap personil yang terlibat dalam manajemen pendidikan memerpulkan satu kesatuan pemahaman untuk menjalankan visi dan misinya. Di sinilah arti penting seorang pemimpin pada struktur manajemen dalam mengejawantahkan visi dan misi lembaga pendidikan yang selaras dengan tujuan pendidikan nasional. ${ }^{2}$

Kepala sekolah sebagai manajer, harus mampu menciptakan suasana yang harmonis dengan guru tanpa mengurangi tugas maupun perannya sebagai pimpinan. Dalam memimpin tersebut, kepala sekolah harus menyadari bahwa guru merupakan kolega atau rekan sejawat, hanya saja sebagai kepala sekollah, ia dibebani tanggung jawab manajerial di lembaga pendidikan. Tanggung jawab manajerial tersebut mengharuskan kepala sekolah menjalankan fungsi manajemen, seperti perencanaan, pengorganisasian, kegiatan, pengawasan, komunikasi maupun melakukan evaluasi terhadap bawahannya di lembaga pendidikan tersebut. ${ }^{3}$ Salah satu jawaban kepala sekolah yang harus dibina adalah guru sebagai pendidik.

Jabatan sebagai kepala sekolah adalah pucuk pimpinan yang akan menerapkan seluruh kegiatannya di sekolah. Akan tetapi, mengelola lembaga pendidikan juga bukanlah

2 Bandingkan dengan Fathonah Al Hadromi, "Analisis Pengarub Gaya Kepemimpinan Kepala Sekolah Terhadap Motivasi, Kedisiplinan Dan Kinerja Guru Di Sd Islam Lumajang", Bisma Jurnal Bisnis dan Manajemen, 11 (1) Januari 2017. Hal. 109 - 123

3 Lihat Andi Rasyid Pananrangi, Manajemen Pendidikan, hal. 21-23, dan Jejen Musfah, Manajemen Pendidikan: Teori, Kebijakan, dan Praktik, Jakarta: Prenada, 2015, hal. 3-5. perkara yang gampang. Seseorang yang memiliki kelebihan saat belum menjabat kepala sekolah, dan ketika diamanahkan untuk memegang jabatan itu, justru malah menimbulkan sisi lemahnya. Kelemahan kepemimpinan tersebut kerap disebabkan oleh jabatan itu sendiri. Akibat lebih lanjut ialah persoalan kredibelitas pimpinan. Artinya telah terjadi pergeseran nilai yang dianutnya dalam memimpin jika dibandingkan dengan sebelum menjadi pemimpin. Ketika belum menjadi kepala sekolah ia menunjukkan sikap positif, namun ketika menduduki jabatan kepala sekolah, sifat positifnya mengalami perubahan kearah yang negatif. Menurunnya kredibilitas kepala sekolah tersebut bukan hanya sekedar sinyalemen, tetapi dapat dilihat dari beberapa tindakan yang dilakukan kepala sekolah. ${ }^{4}$

Problematika yang demikian itu bisa terjadi pada seluruh lembaga pendidikan. Dalam perspektif manajemen, pemimpin yang demikan itu akan sulit untuk menjalankan roda organisasi lembaganya dengan baik sehingga dampaknyapun tidak maksimal terhadap lembaga pendidikan. Karena itulah, cela yang terdapat itu perlu mendapatkan perhatian dari peneliti agar melahirkan kontribusi pemikian yang aplikatif untuk dunia pendidikan di Indonesia.

Maka, berlandaskan latar belakang di atas, penulis tertarik untuk melihat manajemen pendidikan sekolah, khusunya terkait dengan persepsi guru terhadap kredibelitas kepala sekolah dan dampaknya terhadap kinerja. Berbagai gejala yang memperlihatkan ketidakcocokan antara kepala sekolah dengan guru bisa di lihat dari efektifitasnya kegiatan yang ada di sekolah itu sendiri sehingga akan memunculkan suatu persepsi tersendiri dari kalangan internal maupun ekternal. Artinya, menjalankan struktur manejemen pendidikan

4 Tommy Suprapto, Pengantar Teori dan Manajemen Komunikasi, Yogyakarta: Medpres, 2009, hal. 29 
memerlukan suatu kecapakan tersendiri agar tidak menjauh dari idealismenya.

Dalam penelitian ini, Madrasah Aliyah (MA) Darul Falah menjadi lokasi penelitian karena dinilai telah memenuhi standar untuk dijadikan obyek penelitian. Sekolah ini berada di lingkungan pesantren yang memiliki pendidikan mulai dari jenjang sekolah dasar atau Madrasah Ibtidaiyah (MI), Madrasah Tsanawiyah (MTs) hingga MA. Selain itu, karakter dari siswa dan tenaga pendidikanya tidak hanya berasal dari lingkungan di dalam pesantren, tetapi juga dari luar pesantren. Situasi dan lingkungan yang demikian memiliki dampak psikologis yang berda bagi masingmasing tenaga penididik. Alasan lainnya, sebagaimana menurut Abuddin Nata, perlunya perhatian terhadap manajemen pendidikan Islam akan berkontribusi positif pada pendidikan nasional. ${ }^{5}$

\section{Metodologi Penelititan}

Berdasarkan latar belakang di atas, penulis merasa tertarik untuk melakukan penelitian tentang kepemimpinan kepala sekolah, dan yang menjadi variabel $\mathrm{X}$ dalam penelitian ini ialah persepsi guru tentang kredibilitas kepala sekolah, sedangkan variabel $\mathrm{Y}$ ialah kinerja guru. Maka, metode penelitian ini menggunakan pendekatan kuantitatif, sedang pola kajian yang digunakan adalah pola korelatif. Karena pendekatan yang dilakukan dengan pendekatan kuantitatif dan kajiannya adalah kajian korelatif, maka penelitian ini menggunakan statistik sebagai pengolahan data yang telah dikumpulkan melalui instrumen pengumpul data.

Sedangkan desain yang dipergunakan adalah desain ex post facto, yaitu penelitian

5 Abuddin Nata, Manajemen Pendidikan: Mengatasi Kelemahan Pendidikan Islam di Indonesia, Jakarta: Prenada, 2018. untuk mengetahui apakah variabel independen (X) menyebabkan terjadinya perbedaan pada variabel dependen $(Y){ }^{6}$ Populasi penelitian ini adalah seluruh guru di MA Darul Falah Batam yang berjumlah 78 orang. Untuk menentukan jumlah sampel dalam penelitian ini diperguakan rumusan penentuan jumlah sampel yaitu ${ }^{7}$ :

$$
\mathrm{n}=\frac{N}{N \cdot d^{2}+1}
$$

Keterangan :

$$
\begin{array}{ll}
\mathrm{n}= & \text { jumlah keseluruhan } \\
\text { penelitian } & \\
\mathrm{d}^{2}= & \text { presesi yang ditetapkan } \\
10 \% &
\end{array}
$$

Dari keterangan rumus yang telah dikemukakan di atas dan diketahui jumlah keseluruhan populasi penulisan ini sebanyak 78 orang guru MA Darul Falah Batam , maka dapat ditentukan sampel penelitian ini sebagai berikut :

$$
\begin{aligned}
& \mathrm{n}=\frac{N}{N \cdot d^{2}+1} \\
& \mathrm{n}=\frac{78}{78(0,1)^{2}+1} \\
& \mathrm{n}=\frac{78}{78(0,01+1)} \\
& \mathrm{n}=\frac{78}{1,78} \\
& \mathrm{n}=43,82 \\
& \mathrm{n}=44 \text { (dibulatkan) }
\end{aligned}
$$

Kemudian untuk mengambil sampel dari lapangan penelitian tersebut tidak ditentukan atau tidak dipergunakan kriteria

6 Ibnu Hajar, Dasar-Dasar Metodologi Penelitian Kuantitatif Dalam Pendidikan, Jakarta: Raja Grafindo Persada, 1996, hal. 345

7 Jalaluddin Rahmat, Metode Penelitian Komunikasi, Bandung: Rosdakarya, 1997, hal. 82. 
tertentu. Akan tetapi pengambilan dengan mempergunakan sistem acak (random) dan tidak ada pemilihan tertentu pada sampel tersebut. Instrumen atau alat pengumpul data dalam penelitian ini menggunakan angket atau kuesioner. Angket ini diberikan kepada responden secara tertutup, artinya jawaban dari pertanyaan yang telah ditetapkan telah tersedia. Responden tinggal memilih satu alternatif saja. Skala penilaian dengan rentangan setuju, kurang setuju dan tidak setuju. Selain itu, digunakan juga wawancara untuk pengumpul data yang berhubungan dengan kinerja guru dan situasi sekolah MA Darul Falah Batam. Wawancara ini dilakukan dengan kepala sekolah.

Data dari lapangan akan dianalisis dengan menggunakan data statistik, hal ini dilakukan karena penelitian ini ialah penelitian survei yaitu penelitian yang mengumpulkan informasi dengan menggunakan kuesioner. ${ }^{8}$ Teknik statistik yang digunakan ialah teknik Chi Kuadrat, yaitu untuk melihat seberapa besar hubungan variabel $\mathrm{X}$ dengan variabel $\mathrm{Y}$. Bentuk rumusnya ialah :

$$
X^{2}=\frac{(f o-f h)}{f h}
$$

Sedangkan untuk mengetahui seberapa besar kekuatan pengaruh yang diberikan variabel $\mathrm{X}$ terhadap varibel $\mathrm{Y}$ maka akan digunakan teknik Korelasi Kontingensi, rumusnya $: X^{2}$

$$
K K=\sqrt{\frac{X^{2}}{X^{2}}+N}
$$

\section{Persepsi Guru kepada Kepala Sekolah}

Menurut hasil penelitian penulis, persepsi guru-guru MA Darul Falah Batam terhadap kepala sekolahnya menunjukkan

${ }^{8}$ Nasri S. dan Sofian, E., Metode Penelitian Survei, LP3ES, Jakarta, 1982, hal. 8. bahwa kepala sekolah MA Darul Falah Batam cukup kredibel sebagai pemimpin. Persepsi guru-guru yang demikian pada gilirannya melahirkan/turut mempengaruhi kinerja guruguru menjadi lebih baik dalam melaksanakan tugas-tugasnya. Kredibilitas kepala sekolah menurut guru-guru responden mencapai $36 \%$, sedangkan yang menganggap kurang kredibel sebanyak $4 \%$ dan yang menganggap tidak kredibel $4 \%$.

Dari persepsi tersebut, maka pola kepemimpinan kepala sekolah masih tergolong mampu menerapkan menajemen orgnisasi yang baik. Hal ini juga terlihat dari kontribusi positif yang diperliharkan oleh responden dalam. Kontribusi yang diberikan variabel persepsi guru tentang kredibilitas kepala sekolah terhadap kinerja guru ternyata signifikan. Dikatakan demikian karena kontribusi yang diberikan melalui teknik korelasi kontingensi mencapai 19,36 \%. Sedangkan 80,64\% lagi berasal dari variabel lain yang tidak menjadi variabel independen atau variabel bebas dalam penelitian ini.

Dengan demikian, hipotesa penelitian ini terbukti dan diterima kebenarannya secara empiris dan positif. Dikatakan demikian karena hasil uji hipotesis dengan teknik Chi Quadrat menunjukkan bahwa Chi Quadrat hitung lebih besar dari Chi Quadrat tabel, yaitu $\mathrm{X}_{\text {hit }}^{2} 11,05$ sedangkan $\mathrm{X}_{\text {tab }}^{2} 7,78$. Hasil di atas juga menunjukkan korelasi positif terhadap interaksi antara kepala sekolah dengan guru sehingga pola komunikasi juga mendorong persepsi guru.

\section{Korelasi antara Persepsi dan Kinerja Guru}

Data di atas perlu menjadi tolok ukur untuk mendiskusikan korelasi antara kinerja guru dan kredibelitas kepala sekolah. Sebab pendidikan siswa di sekolah sesungguhnya sangat ditentukan oleh kinerja guru-gurunya serta kemampuan manajemen organisasi dari seluruh perangkat dan pemangku kebijakan di 
lingkungan sekolah. ${ }^{9}$ Akan tetapi, peran guru sangat signifikan sebab gurulah yang secara langsung bertugas mendidik dan mentransfer nilai-nilai keilmuan yang dimilikinya pada anak didik. Karena itu mempersiapkan tenaga guru yang menunjukkan kinerja yang baik merupakan tantangan bagi setiap kepala sekolah.

Harus diakui bahwa kinerja guru dalam melaksanakan tugasnya masih dipengaruhi oleh faktor-faktor lain seperti faktor kepemimpinan kepala sekolah. Artinya, kepemimpinan kepala sekolah akan turut mempengaruhi kinerja guru-guru dalam melaksanakan tugasnya dengan baik. Karena itu seorang kepala sekolah haruslah menunjukkan pola kepemimpinan yang baik sehingga dipandang kredibel oleh guru-guru yang dipimpinnya. Tanpa adanya kepemimpinan sebuah lembaga atau organisasi tidak akan mampu mencapai tujuannya. Lembaga pendidikan memiliki tujuan untuk meningkatakan pendidikan ideografik terhadap setiap individu berdasarkan potensi dalam dirinya dan pendidikan nomotetik yang lebih melembagakan tujuan lembaga pendidikan kedalam karakter ideografik peserta didik. ${ }^{10}$

Dalam teori kepemimpinan dalam pendidikan, ada beberapa kriteria yang harus dimiliki oleh kepala sekolah yang dipandang baik dan kredibel oleh guru-guru yang dipimpinnya, antara lain adalah sehat jasmani dan rohani, berwawasan luas dan memahami tugas dan fungsinya, berwibawa, jujur, konsekwen dan bertanggung jawab serta adil dalam memberikan hukuman. Sedangkan model kepemimpinan sebagaimana dikutip Husaini Usman dari $\mathrm{T}$ Bush meliputi

9 Mintarsih Danumiharja, Profesi Tenaga Kependidikan, Yogyakarta: Deepublish, 2014, hal. 23.

10 Murniati AR dan Nasir Usman, Implementasi Manajemen Stratejik Dalam Pemberdayaan Sekolah Menengah Kejuruan, Bandung: Citapustaka Media Perintis, 2009. hal. 12 kepemimpinan (1) manajerial; (2) partisipatif; (3) transformasional; (4) distributif; transaksional; (6) post modern; (7) emosional; (8) kontingensi; (9) moral; (10) instruksional; dan (11) kewirausahaan. ${ }^{11}$

Dalam manajemen sekolah yang menjadi lokasi penelitian, terlihat menerapkan praktik kepemimpinan distributif dan partisipatif. Pasalnya, dalam struktur kepemimpinan sekolah tidak hanya hanya ada kepala sekolah seorang yang memiliki kewenangan, melainkan juga didistribusikan kepada dua wakil kepala sekolah, yakni wakil bidang kesiswaan dan bidang kurikulum. Dengan pola yang demikian, partisipasi seluruh pengisi posisi struktural dan tenaga fungsionalnya sangat penting dalam mencapai visi dan misi sekolah. ${ }^{12}$ Maka, yang perlu menjadi tolok ukur untuk masing-masing kinerja pelaku ialah bergantung pada tugas dan fungsinya.

Yang tidak kalah penting dalam hubungan kausal pemimpin dan anggotanya ialah persepsi dari masing-masing. Maka, tidak heran apabila persepsi diartikan sebagai proses pengorganisasian, penginterpretasian terhadap suatu stimulus yang telah diterima oleh individu sehingga merupakan aktivitas yang sudah integrated dalam diri individu, serta sesuatu yang mempunyai arti bagi individu. ${ }^{13}$ Misalnya, persepsi pimpinan sangat menentukan dalam menjalin pola kumunikasi dengan anggota, begitu juga persepsi anggota sangat berpengaruh terhadap instruksi pimpinan.

Dari hasil penelitian, persepsi guru terhadap kredibilitas kepala sekolah menurut

${ }^{11}$ Husaini Usman, Model Kepemimpinan Instruksional Kepala Sekolah, Jurnal Cakrawala Pendidikan, No.3 Tahun 34, Oktober 2015. Hal. 324

12 Murniati A.R, Manajemen Stratejik: Peran Kepala Sekolah dalam Pemberdayaan, Bandung: Citapustaka Media Perintis, 2008, hal. 75

13 Tommy Suprapto, Pengantar Teori dan Manajemen Komunikasi, Yogyakarta: Medpres, 2009, hal. 22 
guru-guru responden mencapai 36 persen, sedangkan yang menganggap kurang kredibel sebanyak 4 persen dan yang menganggap tidak kredibel 4 persen. Hal ini memperlihatkan bahwa kredibelitas kepala sekolah masih dalam tahapan kredibel namun juga berpotensi menjadi tidak kredibel. Hal ini terlihat dari angka yang begitu dekat antara keduanya sehingga diperlukan upaya untuk meningkatkan persepsi kredibelitas tersebut.

Meski demikian, sebagai sebuah organisasi, kinerja guru masih tergolong baik karena tingkat kinerja profesional keguruan yang dimiliki guru mencapai 86 persen dari guru-guru responden. Artinya mereka memiliki kinerja pada kategori baik, sedangkan yang kurang baik mencapai 6,8 persen dan yang tidak baik 6,8 persen. Hal ini mengindikasikan bahwa pada penelitian ini, terjadi korelasi positif antara persepsi guru kepada kredibelitas kepala sekolah dengan kinerja guru berdasarkan responden penelitian ini. Meski demikian, masih ada 14 persen yang membutuhkan perhatian untuk memaksimalkan kinerja. Hal ini juga menjadi catatan penting untuk perbaikan persepsi guna mencapai visi dan misi sekolah.

Hubungan persepsi lebih menekankan pada pola komunikasi yang dibangun antara kepala sekolah dengan guru, bukan berdasarkan pada pola manajerial yang ada dalam organisasi. Sedangkan hubungan kinerja lebih dekat dengan motivasi. Motivasi dalam manajemen disebut juga sebagai motivasi kerja, yaitu suatu model dalam menggerakkan dan mengarahkan para karyawan agar dapat melaksanakan tugasnnya masing-masing dalam mencapai sasaran dengan penuh kesadaran, kegairahan dan bertanggung jawab. Hasil dari motivasi ini ialah kinerja anggota organisasi.

Dalam kajian manajemen, motivasi menjadi bidang kajian yang menarik sebab banyak melibatkan aspek-aspek psikologis yang menjelaskan terjadinya prilaku anggota dalam organisasi. Sebab, motivasi menjadi menjadi salah satu faktor penting dalam menentukan kinerja dan prestasi. ${ }^{14}$ Misalanya, individu yang memiliki motivasi kerja tinggi akan diiringi dengan semangat bekerja dengan penuh rasa senang dan mendapatkan kepuasan dengan pekerjaannya.

Dalam manajemen berbasis stategis, kinerja guru tidak hanya dihasilkan dari persepsi terhadap pimpinan, meliankan sebuah bentuk pengejawantahan dari visi dan misi organisasi, dalam hal ini tujuan pendidikan nasional secara umum, dan target pencapaian prestasi pendidikan di sekolah secara khusus. Idealnya, gerak seluruh organisai haruslan mengejawantahkan visi dan misi dari sekolah dalam mencapai targetnya, baik target jangka panjang maupun jangka pendek. ${ }^{15}$

Dengan hasil analisa data yang telah disebutkan, responden menunjukkan jawaban yang ideal dalam pola hubungan manajemen partisipatif antara kepala sekolah dengan guru. Meski demikian, hal ini juga bisa mempengaruhi responden dalam memberikan jawaban sehingga berupaya menampilkan sisi baik dari pertanyaan yang diajukan. Dengan demikian, persepsi guru terhadap kredibelitas kepala sekolah masih memperlihatkan kepercayaan yang baik sehingga menjadi motivasi bagi guru untuk mempertahankan kinerjanya. Akan tetapi, secara teoritis, hubungan antara pola komunikasi dan pola manajeman masih perlu mendapatkan perhatian lebih lanjut agar bisa mengungkap

${ }^{14}$ Lihat hasil penelitian Riyadi, S. (2011), Pengaruh kompensasi finansial, gaya kepemimpinan, dan motivasi kerja terhadap kinerja karyawan pada perusahaan manufaktur di Jawa Timur, Jurnal manajemen dan kewirausahaan, 13(1), 40-45. https://doi.org/10.9744/jmk.13.1.40-45. dan dan Biatna Dulbert Tampubolon, Analisis faktor gaya kepemimpinan dan faktor etos kerja terhadap kinerja pegawai pada organisasi yang telab menerapkan SNI 19-9001-2001," Jurnal standardisasi 9.3 (2007): 106-115. http://dx.doi.org/10.31153/js.v9i3.684

15 Murniati A.R, Manajemen Stratejik. hal. 75 dan 108

Perada, Vol. 1, No. 1, Juni 2018 
secara komprehensif relasi antara persepsi dan kinerja.

\section{Kesimpulan}

Guru memiliki peran penting dalam mencapai tujuan pendidikan ideografik dan nomotetik. Keberadaannya juga tidak lepas dari korelasi yang baik dengan pimpinan, yakni kepala sekolah. Dalam analisa data atas sampel penelitian ini, diketahui bahwa persepsi guru terhadap kredibelitas kepala sekolah mempengaruhi kinerja guru itu sendiri. Guru di MA Darul Falah masih menilai kredibelitas kepala sekolah cukup baik sehingga movitasi kerjanya juga masih membaik. Hal ini dibuktikan dengan adanya prestasi yang tetap dipertahankan di sekolah tersebut. Dalam penelitian ini juga terungkap bahwa persepsi dan kinerja tidak sepenuhnya karena faktor kepemimpinan dalam manajemen, melainkan juga faktor psikologis dan komunikasi yang turut membantu membangun persepsi terebut. Sehingga, manajemen strategis yang diterapkan dalam sekolah pun belum sepenuhnya bisa menjadi pemantik semangat bersama untuk mencapai tujuan pendidikan, melainkan hanya disebabkan oleh adanya faktor kepemimpinan.[] 


\section{Daftar Pustaka}

Danumiharja, Mintarsih, Profesi Tenaga Kependidikan, Yogyakarta: Deepublish, 2014.

Hadromi, Fathonah Al, "Analisis Pengaruh Gaya Kepemimpinan Kepala Sekolah Terhadap Motivasi, Kedisiplinan Dan Kinerja Guru Di Sd Islam Lumajang”, Bisma Jurnal Bisnis dan Manajemen, 11 (1) Januari 2017.

Hajar, Ibnu, Dasar-Dasar Metodologi Penelitian Kuantitatif Dalam Pendidikan, Jakarta: Raja Grafindo Persada, 1996.

Murniati A.R, Manajemen Stratejik: Peran Kepala Sekolah dalam Pemberdayaan, Bandung: Citapustaka Media Perintis, 2008.

Murniati AR dan Nasir Usman, Implementasi Manajemen Stratejik Dalam Pemberdayaan Sekolab Menengah Kejuruan, Bandung: Citapustaka Media Perintis, 2009.

Musfah, Jejen, Manajemen Pendidikan: Teori, Kebijakan, dan Praktik, Jakarta: Prenada, 2015.

Nasri, S. dan Sofian, E., Metode Penelitian Survei, LP3ES, Jakarta, 1982.

Nata, Abuddin, Manajemen Pendidikan: Mengatasi Kelemahan Pendidikan Islam di Indonesia, Jakarta: Prenada, 2018.

Pananrangi, Andi Rasyid, Manajemen Pendidikan, Celebes Media Perkasa, 2017.

Rahmat, Jalaluddin, Metode Penelitian Komunikasi, Bandung: Rosdakarya, 1997.

Riyadi, Slamet, Pengaruh kompensasi finansial, gaya kepemimpinan, dan motivasi kerja terhadap kinerja karyawan pada perusahaan manufaktur di Jawa Timur, Jurnal manajemen dan kewirausahaan, 2011, 13(1), 40-45. https://doi.org/10.9744/jmk.13.1.40-45.

Suprapto, Tommy, Pengantar Teori dan Manajemen Komunikasi, Yogyakarta: Medpres, 2009.

Tampubolon, Biatna Dulbert, Analisis faktor gaya kepemimpinan dan faktor etos kerja terhadap kinerja pegawai pada organisasi yang telah menerapkan SNI 19-9001-2001," Jurnal standardisasi 9.3 (2007): 106-115. http://dx.doi.org/10.31153/js.v9i3.684

Usman, Husaini Model Kepemimpinan Instruksional Kepala Sekolah, Jurnal Cakrawala Pendidikan, No.3 Tahun 34, Oktober 2015. 